\title{
Agronomic Evaluation and Physiological Quality in Triticale, under Two Production Systems in the Laguna Region
}

\author{
Lecona-Garcia Ruben ${ }^{1}$, Flores-Naveda Antonio ${ }^{2^{*}}$, Lozano-del-Rio Alejandro J. ${ }^{3}$, Ruiz-Torres Norma Angélica ${ }^{2}$, \\ Vázquez-Badillo Mario Ernesto ${ }^{2}$ \\ ${ }^{1}$ Programa de Maestría en Tecnología de Granos y Semillas. Departamento de Fitomejoramiento. Universidad \\ Autónoma Agraria Antonio Narro. \\ ${ }^{2}$ Centro de Capacitación y Desarrollo en Tecnología de Semillas. Departamento de Fitomejoramiento. \\ Universidad Autónoma Agraria Antonio Narro. Buenavista, Saltillo, Coahuila, México. C.P. 25315. \\ ${ }^{3}$ Departamento de Fitomejoramiento. Universidad Autónoma Agraria Antonio Narro. Buenavista, Saltillo, \\ Coahuila, México. C.P. 25315. \\ *Corresponding author: naveda26@hotmail.com
}

\begin{abstract}
Objective: To evaluate ten triticale genotypes to assess the quality of the seeds under two production systems, with cut and without cut, in the municipalities of Matamoros (L1) and Francisco I. Madero (L2), Coahuila, Mexico.

Design/Methodology/Approach: The agronomic variables evaluated were: Grain yield (GY), number of seeds per spike (NSS), spike length (SL), number of spikelets per spike (SS) and plant height (PH). Variables in the laboratory were: normal seedlings (NS), abnormal seedlings (AS), seeds without germinating (SWG), dry seedling weight (DW), plumule length (PL) and radicle length (RL). Statistical analysis was performed with the PROC ANOVA procedure, of the SAS software.

Results: A higher grain yield was found for Matamoros (L1) compared to Francisco I. Madero (L2); however, for the variable number of seeds per spike it was higher in the latter (L2). For the physiological quality of seeds in L2, the highest values were in the variables normal seedlings and radicle length. In the comparison of production systems, the best response was for the system without cut in both locations; therefore, good quality triticale seed can be produced with acceptable grain yield.

Study Limitations/Implications: It is necessary to describe the performance of triticale in the springsummer agricultural cycle in the central region of the country.

Findings/Conclusions: The productive performance of triticale genotypes was variable depending on the production system, and there was also a different effect on the physiological quality of the harvested seed.
\end{abstract}

Keywords: Triticale, seeds, quality, systems.

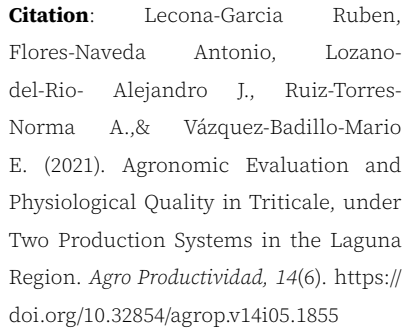

Editor in Chief: Dr. Jorge Cadena Iñiguez

Estimated publication date: July 2021

This work is licensed under a Creative Commons Attribution-NonCommercial 4.0 International license

\section{INTRODUCTION}

Triticale (X Triticum secale Wittmack) is a cereal product of breeding between wheat (Triticum aestivum L.) and rye (Secale cereale L.). Its name has been formed with half of the name of each of the genera of its parents (CIMMYT, 1976). Currently, this crop represents an option as a fodder crop since it has characteristics such as high productivity, adequate resistance to diseases and pests, tolerance to stress, high capacity for nutrient absorption, superior nutritional quality, and fast establishment in comparison to traditional crops such as oats, wheat or rye (Guinta et al., 2015; Velázquez, 2018), making it a good alternative to decrease the deficit of fodders for animal diets.

In Mexico, during 2019, according to the Service for Agrifood and Fishing Information (Servicio de Información Agroalimentaria y Pesquera, SIAP), 24,604.24 hectares of triticale were harvested for fodder, grain and seed. In the Comarca Lagunera that includes the 
states of Coahuila and Durango, SIAP 2019 reported on the triticale crop for fodder use, a surface of 1,345.9 hectares harvested with a production volume of 49,387.6 t, with an average yield per hectare of 36.28 tons. According to the SNICS 2020 (National Service of Inspection and Certification of Seeds, Servicio Nacional de Inspección y Certificación de Semillas), three hectares of the AN-184 variety were harvested for the production of qualified triticale seed.

Triticale cultivation represents a valuable alternative due to its acceptable biomass production and grain yield, for animal feed (Estrada et al., 2012; Bassu et al., 2013); it exceeds wheat in biomass production, and has greater resistance to leaf diseases and to marginal production conditions (Ammar, 2013). Presently, in northeastern Mexico it represents an alternative as fodder plant, due to its good capacity for regrowth, allowing several cuts and being more competitive than ryegrass, barley or oats (Ammar, 2013), in addition to having a greater content of nutrients. Currently, this crop is gaining presence because of the productive reconversion in some fodder and grain producing zones of the country, substituting some traditional crops. The use of this cereal in Mexico is predominantly for fodder production (plant), and its grain as supplement to diets for animal consumption, mainly monogastric; also, for human diet, as bread grain flour mixed with wheats.

The generation of fodder varieties with an adequate production and seed quality is sought today; this aspect is lacking updated information with regard to the new varieties of this crop, which is a limitation for the production and liberation of new commercial varieties that comply with the demands of the seed market. Therefore, the objective of this study was to evaluate the triticale seed harvested in two production systems (with cut and without cut), as well as their effect on the physiological quality at the laboratory level.

\section{MATERIALS AND METHODS \\ Experimental site}

This study was carried out during the 2018-2019 fall-winter agricultural cycle in two localities of the Comarca Lagunera Region in the state of Coahuila, Mexico. The first locality was Rancho El Campanario in the municipality of Matamoros, located between $25^{\circ} 30^{\prime} 01.6^{\prime \prime}$ Latitude $\mathrm{N}$ and $103^{\circ} 09^{\prime} 20.9^{\prime \prime}$ Longitude W, with an altitude of 1,120 masl. The mean maximum temperature is $31.5^{\circ} \mathrm{C}$, the mean minimum temperature is $12.9^{\circ} \mathrm{C}$, and the mean temperature is $22.9^{\circ} \mathrm{C}$. The mean annual rainfall is $176.1 \mathrm{~mm}$ (SMN, 2019). The predominant soil type is Xerosol. The climate is very dry semi-warm (100\%) (INEGI, 2009). The second locality was Establo Lanchares in the municipality of Francisco I. Madero, located between the coordinates $25^{\circ} 54^{\prime} 24^{\prime \prime}$ Latitude N and $103^{\circ}$ 17 ' 45" Longitude $\mathrm{W}$, with an altitude of 1,100 masl. The mean maximum temperature is $28.2^{\circ} \mathrm{C}$, the mean minimum temperature is $11.2^{\circ} \mathrm{C}$ and the mean temperature is 19.7 ${ }^{\circ} \mathrm{C}$. The mean annual rainfall is $189.6 \mathrm{~mm}(\mathrm{SMN}, 2019)$. The predominant soil type is Xerosol and Leptosol. The type of climate is dry semi-warm (86\%) and dry very warm and warm (14\%) (INEGI, 2009). 


\section{Triticale germplasm}

Ten genotypes of triticale from the Cereals Program of the Plant Breeding Department of Universidad Autónoma Agraria Antonio Narro were used, as well as a commercial variety, for sowing in both localities. The names of the genotypes used are the following: F2-1, F3-23, F13-17, F14-9, F3-13, F6-23, F16-12, F6-14, AN-184, and Bicentenario. For cultivation, the tasks carried out were: terrain preparation for sowing cereals in the region, plowing, dragging, leveling and furrowing. Sowing in Matamoros, Coahuila, was done on December 3, 2018, and in the locality of Francisco I. Madero, it was on December 5, 2018. They were both done manually, by seed drilling in the bottom of the furrow. A sowing density of $110 \mathrm{~kg} / \mathrm{ha}$ was used, adjusting to the size of the plot. Each experimental unit was six furrows with $0.30 \mathrm{~m}$ of spacing by $10 \mathrm{~m}$ of length, with a surface per plot of $18 \mathrm{~m}^{2}$. Gravity fed irrigation was applied to the experiments immediately after sowing. Then, four helping irrigations were applied on the stages of tillering, setting, flowering and grain filling; however, irrigation was added for the triticale with cut after cutting in both localities. Regarding weed control, Triasulfuron was applied (10 g/ha) during the stage of tillering. In the experiment with cut, it was done at 75 days after sowing in both localities, cutting the totality of the plot with a mechanical reaper, at an approximate cutting height of $4-5 \mathrm{~cm}$.

\section{Threshing and seed conditioning}

Threshing was carried out in the building of the Cereals Program of the Plant Breeding Department, with a stationary threshing machine for small grain cereals. The seed obtained as a result of the threshing process was transferred to the Seed Conditioning Laboratory in the Training and Development Center in Seed Technology of the UAAAN, where the process of conditioning was applied through an air-sieve machine (Clipper ${ }^{\oplus}$ ) for the laboratory, and that is where the seed was cleaned of impurities (stubbles) and the seeds with mechanical damage were eliminated.

\section{Variables evaluated at the field and laboratory level}

At the field level, the agronomic variables evaluated were: plant height (PH), which was measured with a measuring tape from the base of the plant to the distal end of the spike, in each experimental unit and in each sampling, recorded in $\mathrm{cm}$. For the variable yield (GY), the threshed seed from each experimental unit was weighed in an electronic scale and recorded in $\mathrm{kg}$. For this variable, the following formula was used: yield estimation $=\left(\mathrm{kg}\right.$ harvested) $\left(\right.$ surface of experimental unit)/10,000 $\mathrm{m}^{2}$. Likewise, the following variables were measured: spike length (SL), where 10 spikes were selected that were measured from the tip to the base with a millimetric sheet and expressed in $\mathrm{cm}$; number of spikelets per spike (SS), where the number of spikelets in each spike of the 10 selected spikes were counted; and number of seeds per spike (NSS), where from each experimental unit the spikes were selected randomly in plants with full competence, threshed manually, and the number of seeds from ten spikes counted. 
In the post-harvest stage at the laboratory level, to determine the physiological quality of the triticale seed, normal seedlings (NS) were evaluated, which were assessed eight days after sowing and consisted in the total count of normal seedlings, and the result expressed in percentage (\%). Abnormal Seedlings (AS): all the seedlings with damaged primary roots, deformities, negative geotropism, without secondary roots, and with low limited vigor limiting their optimal development, were considered as abnormal seedlings, and the result expressed in percentage (\%). Seeds without germinating (SWG): the seeds that did not present any sign of radicle emergence were counted and the result was expressed in percentage (\%). Length of plumule and of radicle (PL) and $(\mathrm{RL})$ : these variables were measured in normal plants, considering those that did not present any abnormality, and measuring each of the structures was carried out using a table with a graduated millimetric sheet in scale of $\mathrm{cm}$. Dry seedling weight (DW): after the previous variables were determined, measuring this variable consisted in depositing all the normal seedlings (NS) by repetition in perforated brown paper bags and identified with the number of repetition and treatment, and then they were placed in a dry stove brand (SHEL LAB ${ }^{\circledR}$ ), at a temperature of $72{ }^{\circ} \mathrm{C}$ during a lapse of $24 \mathrm{~h}$. After such time the samples were placed in a desiccator with the aim of avoiding them becoming moistened from the environment, and not affecting data taking. Later, the samples of each repetition were weighed in an analytic scale (OHAUS $\left.{ }^{\circledR}\right)$, to determine the value of the dry weight and it was represented in $\mathrm{mg} /$ seedling.

\section{Experimental design and statistical analysis}

The experimental design used in the field was complete random blocks with factorial arrangement (2 localities $\times 2$ production systems $\times 10$ genotypes) with three repetitions.

In the linear model the following factors were considered: Localities (Locality 1 Matamoros and Locality 2 Francisco I. Madero), Production Systems (without cut and with cut) and Varieties (10 triticale genotypes).

The statistical analysis was performed considering the genotypes evaluated in the two localities, with their corresponding means comparison tests (Tukey, P $\leq 0.05$ ) using the SAS statistical package version 9.0 (SAS Institute, Caray, NC, USA, 2004). The statistical model of the variables evaluated in the laboratory was performed according to a completely random experimental design with factorial arrangement (2 localities $x$ 2 production systems $\times 10$ genotypes).

\section{RESULTS AND DISCUSSION}

The variable (GY) showed a highly significant difference $(\mathrm{P} \leq 0.01)$ in localities, systems and in the interactions localities by systems and systems by variety (Table 1). For varieties and the triple interaction, there was significant difference $(\mathrm{P} \leq 0.05)$. For the variable (NSS) there was a highly significant difference $(\mathrm{P} \leq 0.01)$ for localities and systems, between variables there was a significance difference $(\mathrm{P} \leq 0.05)$. For the variable (SL) a highly significant difference was found $(\mathrm{P} \leq 0.01)$ in varieties and in the 
interaction systems by varieties. For varieties there was a significant difference for localities and systems. For the variable (SS) a highly significant difference was found $(\mathrm{P} \leq 0.01)$ in localities and varieties. For systems and the interactions localities by varieties and localities by systems by varieties there was significant difference. For the variable $(\mathrm{PH})$ a highly significant difference was found $(\mathrm{P} \leq 0.01)$ for localities, varieties, and the interaction systems by varieties. A significant difference was seen for systems and the interaction of localities by systems by varieties. Next, Table 2 shows the means comparison test (Tukey $\geq 0.05$ ) of the variables evaluated in the field.

Table 1. Analysis of variance for agronomic variables in triticale genotypes.

\begin{tabular}{c|c|c|c|c|c|c}
\hline $\begin{array}{c}\text { Source of } \\
\text { variation }\end{array}$ & DF & $\begin{array}{c}\text { Grain yield } \\
\left(\mathbf{G Y} ; \mathbf{t ~ h a} \mathbf{~}^{\mathbf{- 1}}\right)\end{array}$ & $\mathbf{N S S}$ & $\mathbf{S L}(\mathbf{c m})$ & $\mathbf{S S}$ & PH $(\mathbf{c m})$ \\
\hline BLOCK & 2 & 12.22 & 11.78 & 1.02 & 4.07 & 118.76 \\
\hline LOC & 1 & $10.77^{* *}$ & $1725.20^{* *}$ & $3.65^{*}$ & $2.16^{* *}$ & $3162.13^{* *}$ \\
\hline SYS & 1 & $8.23^{* *}$ & $4212.67^{* *}$ & $3.46^{*}$ & $29.00^{*}$ & $634.08^{*}$ \\
\hline VAR & 9 & $1.32^{*}$ & $216.95^{*}$ & $4.24^{* *}$ & $76.21^{* *}$ & $4143.51^{* *}$ \\
\hline LOC*SYS & 1 & $5.54^{* *}$ & 3.67 & 8.64 & 6.07 & 5.20 \\
\hline LOC*VAR & 9 & 0.60 & 142.63 & 2.18 & $23.32^{*}$ & 206.32 \\
\hline SYS*VAR & 9 & $2.79^{* *}$ & 130.98 & $3.76^{* *}$ & 12.69 & $759.87^{* *}$ \\
\hline LOC*SYS*VAR & 9 & $1.16^{*}$ & 154.61 & 1.05 & $17.38^{*}$ & $312.64^{*}$ \\
\hline ERROR & 78 & 330.08 & 66.78 & 0.60 & 7.10 & 92.48 \\
\hline MEAN & & 1.66 & 43.25 & 12.47 & 27.32 & 97.6 \\
\hline C.V. $\%$ & & 34.93 & 18.69 & 6.27 & 9.7 & 9.88 \\
\hline
\end{tabular}

** Significant at the $(\mathrm{P} \leq 0.01)$ probability level; Significant at the * $(\mathrm{P} \leq 0.05)$ probability level; D. F: degrees of freedom; LOC=location; SYS=systems; VAR=varieties; C. V: coefficient of variation. Grain yield/t ha ${ }^{-1}$ $(G Y)=$ Grain yield per hectare; NSS=Number of seeds per spike; SL= Spike length; SS= Number of spikelets per spike; $\mathrm{PH}=$ Plant height.

For (GY) in the case of L1, there was a higher yield in comparison than in L2, which had an influence on the agronomic management that it was given because in L2 irrigation was not applied at the time when the crop demanded it, so the yield decreased in comparison to L1. The difference in relation between systems was that a higher yield was found without cut compared to where cutting was done, because the cut interrupted the vegetative cycle, and therefore, the plant reduced its capacity for regrowth and seed production. For the case of varieties, the one with higher yield was variety 1 with an average yield of 2.12 tons per hectare, due to its precocity exceeding the control (Bicentenario). However, according to Mendoza et al. (2011) there were values that ranged between 6.61 and 1.4 tons per hectare. For (NSS) in the case of L1 there was a lower number of seeds than in L2, because the plants in L2 presented higher stress due to the environmental conditions, in addition to the agronomic management which impacted the yield. Between the systems without cut and with cut there was a higher number of seeds in the system without cut because the crop was kept without the fodder cut, and with the cut performed there was lower regrowth and therefore the plant was only able to produce spikes, but with lower vigor, which generated a 
lower number of seeds per spike. Within the varieties, the values presented a similar trend, although variety 7 of late habit was the one that presented the highest average value of 54 seeds per ear, which is why this is directly linked to the number of spikelets per spike, according to Velasco et al. (2020) who obtained higher results fluctuating between 73 and 59 (NSS). However, Paccapelo et al. (2017) reported values that ranged between 39 and 28 seeds per spike. According to the results reported by Beji (2016), for the number of seeds per spike, it reports values of 34 to 20 seeds per spike in triticale.

Table 2. Comparison test of means for agronomic variables in triticale genotypes.

\begin{tabular}{|c|c|c|c|c|c|c|}
\hline & $\begin{array}{l}\text { Source of } \\
\text { variation }\end{array}$ & $\begin{array}{l}\text { Grain yield } \\
\left(\text { GY; t ha }{ }^{-1}\right)\end{array}$ & NSS & $\begin{array}{c}\text { SL } \\
(\mathrm{cm})\end{array}$ & SS & $\begin{array}{c}\text { PH } \\
(\mathbf{c m})\end{array}$ \\
\hline \multirow{2}{*}{ LOC } & Matamoros & $1.96 \mathrm{a}$ & $39.46 \mathrm{~b}$ & $12.64 \mathrm{a}$ & $29 \mathrm{a}$ & $92.47 \mathrm{~b}$ \\
\hline & Fco. I. Madero & $1.36 \mathrm{~b}$ & $47.05 \mathrm{a}$ & $12.29 \mathrm{~b}$ & $26 \mathrm{~b}$ & $102.74 \mathrm{a}$ \\
\hline \multicolumn{2}{|r|}{ MSD } & 210.96 & 2.93 & 0.28 & 0.96 & 3.50 \\
\hline \multirow{2}{*}{ SYS } & Without cut & $2.49 \mathrm{a}$ & $49.18 \mathrm{a}$ & $12.64 \mathrm{a}$ & $28 \mathrm{a}$ & $99.90 \mathrm{a}$ \\
\hline & With cut & $0.83 \mathrm{~b}$ & $37.33 \mathrm{~b}$ & $12.30 \mathrm{~b}$ & $27 \mathrm{~b}$ & $95.30 \mathrm{~b}$ \\
\hline \multicolumn{2}{|r|}{ MSD } & 210.16 & 2.93 & 0.28 & 0.96 & 3.50 \\
\hline \multirow{10}{*}{ VAR } & F2-1 & $2.12 \mathrm{a}$ & $37.08 \mathrm{~b}$ & $11.56 \mathrm{~d}$ & $23 c$ & $117.37 \mathrm{a}$ \\
\hline & F3-23 & $1.71 \mathrm{abc}$ & $44.08 \mathrm{ab}$ & $12.86 \mathrm{abc}$ & $28 \mathrm{ab}$ & $84.70 \mathrm{~b}$ \\
\hline & F13-17 & $1.33 \mathrm{bc}$ & $43.41 \mathrm{ab}$ & $12.20 \mathrm{bcd}$ & $26 \mathrm{bc}$ & $112.58 \mathrm{a}$ \\
\hline & F14-9 & $1.15 \mathrm{C}$ & $42.75 \mathrm{~b}$ & $12.59 \mathrm{abcd}$ & $28 \mathrm{ab}$ & $80.20 \mathrm{~b}$ \\
\hline & Bicentenario & $2.02 \mathrm{ab}$ & $42.33 \mathrm{~b}$ & $11.83 \mathrm{~cd}$ & $24 \mathrm{C}$ & $116.18 \mathrm{a}$ \\
\hline & F3-13 & $1.49 \mathrm{abc}$ & $42.75 \mathrm{~b}$ & $12.47 \mathrm{abcd}$ & $29 \mathrm{ab}$ & $82.45 \mathrm{a}$ \\
\hline & F6-23 & $1.79 \mathrm{abc}$ & $54.08 \mathrm{a}$ & $11.97 \mathrm{~cd}$ & $30 \mathrm{a}$ & $114.54 \mathrm{a}$ \\
\hline & F16-12 & $1.98 \mathrm{ab}$ & $42.66 \mathrm{~b}$ & $13.47 \mathrm{a}$ & $30 \mathrm{a}$ & $79.25 \mathrm{~b}$ \\
\hline & F6-14 & $1.72 \mathrm{abc}$ & $41.41 \mathrm{~b}$ & $12.95 \mathrm{ab}$ & $29 \mathrm{ab}$ & $114.41 \mathrm{a}$ \\
\hline & AN-184 & $1.28 \mathrm{bc}$ & $42 \mathrm{~b}$ & $12.86 \mathrm{abc}$ & $28 \mathrm{ab}$ & $74.33 \mathrm{~b}$ \\
\hline \multicolumn{2}{|r|}{ MSD } & 771.46 & 10.74 & 1.04 & 3.52 & 12.82 \\
\hline
\end{tabular}

$\mathrm{LOC}=$ location; $\mathrm{SYS}=$ systems; $\mathrm{VAR}=$ varieties; $\mathrm{MSD}=$ Minimum significant difference; Grain yield/ton ha ${ }^{-1}$ $(G Y)=$ Grain yield per hectare; NSS=Number of seeds per spike; SL=Spike length; $S S=$ Number of spikelets per spike; $\mathrm{PH}=$ Plant height. Within columns, means followed by the same letter are not significantly different according to Tukey $(\mathrm{P} \leq 0.05)$.

In the means comparison test for the variable spike length (SL) for the case of the localities, in L1 there was a length of $12.64 \mathrm{~cm}$ which was the highest and in L2 a length of $12.29 \mathrm{~cm}$. For the case of the systems, the system without cut had the longest length of $12.64 \mathrm{~cm}$ and the system with cut a length of $12.30 \mathrm{~cm}$, very similar values to those of the localities. For the varieties, variety 8 was the one that presented the highest value with a longitude of $13.47 \mathrm{~cm}$, with the other varieties ranging between 11 and $13 \mathrm{~cm}$, similar to what was reported by Velasco et al. (2020). In the means comparison test for the variable number of spikelets per spike (SS) in the case of localities, L1 presented the highest value with 29 spikelets per spike and L2 with a value of 26 spikelets per spike. In the case of the production systems, the system without cut had the highest value with 28 spikelets per spike and the system with cut a value of 27 spikelets per spike. In the case of the varieties, varieties 7 and 8 shared the same letter with the highest value 
of 30 spikelets per spike, values similar to those mentioned by Velasco et al. (2020). It is important for this variable to be related to (NSS) since that is where it is related to the fertility of the spikelet and which is directly related to grain production. In the means comparison test for the variable (PH) in the case of the localities, L2 presented higher height with a value of $102.74 \mathrm{~cm}$ and L1 with a value of $92.47 \mathrm{~cm}$. In the case of the production systems, the system without cut with a value of $99.90 \mathrm{~cm}$ and the system with cut with a value of $95.30 \mathrm{~cm}$. For the case of varieties, five behaved with the same letter with the following values: variety 1 with $117.37 \mathrm{~cm}$, variety 5 with $116.18 \mathrm{~cm}$, variety 7 with $114.54 \mathrm{~cm}$, variety 9 with $114.41 \mathrm{~cm}$ and lastly, variety 3 with $112.58 \mathrm{~cm}$; likewise, the values reported by Mendoza et al. (2014) were exceeded. Next, Table 3 presents the analysis of variance with the attributes of physiological quality in triticale seeds.

Table 3. Analysis of variance for physiological quality in triticale seeds, evaluated at the laboratory.

\begin{tabular}{|c|c|c|c|c|c|c|c|}
\hline $\begin{array}{l}\text { Source of } \\
\text { variation }\end{array}$ & DF & $\begin{array}{l}\text { NS } \\
(\%)\end{array}$ & $\begin{array}{c}\text { AS } \\
(\%)\end{array}$ & $\begin{array}{c}\text { SWG } \\
(\%)\end{array}$ & $\begin{array}{c}\text { DW } \\
\text { (mg/ } \\
\text { seedling) }\end{array}$ & $\begin{array}{c}\text { PL } \\
(\mathbf{c m})\end{array}$ & $\begin{array}{c}\text { RL } \\
(\mathbf{c m})\end{array}$ \\
\hline LOC & 1 & 1114.82 & $2110.44^{* *}$ & 433.50 & 366.93 ** & 103.61 & $713.74^{* *}$ \\
\hline SYS & 1 & 40987.56 ** & $46510.15^{\text {** }}$ & 27.21 & 55.64 & 3.07 & 62.67 \\
\hline VAR & 9 & $1765.26^{\star \star}$ & $1330.55^{\star \star *}$ & 95.07 & 45.91 ** & 102.83 & 70.07 ** \\
\hline LOC*SYS & 1 & $17941.76^{* \star}$ & $13417.31^{* *}$ & 643.34 ** & 8.15 & 92.66 & 13.26 \\
\hline $\mathrm{LOC}^{*} \mathrm{VAR}$ & 9 & $617.17^{* *}$ & 1076.70 & 40.58 & 13.38 & 77.13 & 45.85 \\
\hline SYS*VAR & 9 & 1325.26 ** & $1495.49 * *$ & 22.75 & $43.25 * *$ & 82.40 & 46.16 \\
\hline LOC*SYS*VAR & 9 & $1172.41^{* *}$ & $897.83^{*}$ & 35.84 & 16.30 & 44.78 & 21.85 \\
\hline ERROR & 384 & 301.33 & 322.62 & 36.24 & 10.52 & 47.36 & 18.14 \\
\hline \multicolumn{2}{|l|}{ MEAN } & 62.11 & 33.55 & 5.21 & 12.15 & 12.46 & 13.91 \\
\hline \multicolumn{2}{|l|}{ C.V.\% } & 27.94 & 53.52 & 115.34 & 26.68 & 55.22 & 30.6 \\
\hline
\end{tabular}

** Significant at the $(\mathrm{P} \leq 0.01)$ probability level; Significant at the * $(\mathrm{P} \leq 0.05)$ probability level; D. F: degrees of freedom; LOC=location; SYS=systems; VAR=varieties; C.V: coefficient of variation. NS=Normal seedlings; AS=Anormal seedlings; SWG=Seeds without germinating; DW=Dry seedling weight; PL=Plumule length; RL=Radicle length.

For normal seedlings (NS) there was a highly significant difference $(\mathrm{P} \leq 0.01)$ in systems, variety and in the interactions localities by systems, localities by varieties, systems by varieties, and localities by systems by varieties. For abnormal seedlings (AS) there was a highly significant difference $(\mathrm{P} \leq 0.01)$ in localities, systems, varieties and in the interactions localities by systems, and systems by varieties. In addition, there was significant difference $(\mathrm{P} \leq 0.05)$ for the interaction localities by systems by varieties. For the variable seeds without germinating (SWG) there was highly significant difference $(\mathrm{P} \leq 0.01)$ for localities by systems. For the variable dry weight (DW) there was highly significant difference $(\mathrm{P} \leq 0.01)$ for localities, varieties and the interaction systems by varieties. For the variable plumule length (PL) there was no significant difference in the treatments. For the variable radicle length (RL) there was highly significant difference $(\mathrm{P} \leq 0.01)$ for localities and varieties. 
Table 4. Comparison test of means for physiological quality in triticale seeds, evaluated at the laboratory.

\begin{tabular}{|c|c|c|c|c|c|c|c|}
\hline \multicolumn{2}{|c|}{ Source of variation } & \multirow{2}{*}{\begin{tabular}{|c|c|}
$\begin{array}{c}\text { NS } \\
(\mathbf{\%})\end{array}$ \\
$61.00 \mathrm{~b}$ \\
\end{tabular}} & \multirow{2}{*}{$\begin{array}{c}\begin{array}{c}\text { AS } \\
(\mathbf{\%})\end{array} \\
35.00 \mathrm{a}\end{array}$} & \multirow{2}{*}{$\begin{array}{c}\begin{array}{c}\text { SWG } \\
(\mathbf{\%})\end{array} \\
4.00 \mathrm{~b}\end{array}$} & \multirow{2}{*}{$\begin{array}{c}\begin{array}{c}\text { DW } \\
\text { (mg/ } \\
\text { seedling) }\end{array} \\
11.29 \mathrm{~b} \\
\end{array}$} & \multirow{2}{*}{$\begin{array}{c}\begin{array}{c}\text { PL } \\
(\mathbf{c m})\end{array} \\
12.00 \mathrm{a} \\
\end{array}$} & \multirow{2}{*}{$\begin{array}{c}\begin{array}{c}\mathbf{R L} \\
(\mathbf{c m})\end{array} \\
12.73 \mathrm{~b} \\
\end{array}$} \\
\hline LOC & Matamoros & & & & & & \\
\hline & Fco. I. Madero & $64.00 \mathrm{a}$ & $31.00 \mathrm{~b}$ & $6.00 \mathrm{a}$ & $13.18 \mathrm{a}$ & $13.01 \mathrm{a}$ & $15.36 \mathrm{a}$ \\
\hline \multicolumn{2}{|r|}{ MSD } & 3.35 & 3.44 & 1.16 & 0.629 & 1.33 & 0.82 \\
\hline \multirow[t]{2}{*}{ SYS } & Without cut & $72.00 \mathrm{a}$ & $23.00 \mathrm{~b}$ & $5.00 \mathrm{a}$ & $12.54 \mathrm{a}$ & $12.38 \mathrm{a}$ & $14.34 \mathrm{a}$ \\
\hline & With cut & $52.22 \mathrm{~b}$ & $44.00 \mathrm{a}$ & $5.00 \mathrm{a}$ & $11.76 \mathrm{~b}$ & $12.53 \mathrm{a}$ & $13.49 \mathrm{~b}$ \\
\hline \multicolumn{2}{|r|}{ MSD } & 3.34 & 3.43 & 1.15 & 0.629 & 1.32 & 0.82 \\
\hline \multirow[t]{10}{*}{ VAR } & F2-1 & $46.50 \mathrm{c}$ & $45.75 \mathrm{a}$ & $7.12 \mathrm{ab}$ & $12.76 \mathrm{abc}$ & $8.62 \mathrm{~b}$ & $12.46 \mathrm{~b}$ \\
\hline & F3-23 & $69.44 \mathrm{a}$ & $26.89 c$ & $3.66 \mathrm{bc}$ & $10.87 \quad \mathrm{c}$ & $13.43 \mathrm{ab}$ & $13.33 \mathrm{~b}$ \\
\hline & F13-17 & $57.50 \mathrm{abc}$ & $37.10 \mathrm{abc}$ & $5.40 \mathrm{abc}$ & $12.45 \mathrm{abc}$ & $11.99 \mathrm{ab}$ & $16.63 \mathrm{a}$ \\
\hline & F14-9 & $68.40 \mathrm{a}$ & $28.80 \quad \mathrm{c}$ & $2.80 \mathrm{c}$ & $12.62 \mathrm{abc}$ & $11.21 \mathrm{ab}$ & $14.85 \mathrm{ab}$ \\
\hline & Bicentenario & $54.00 \mathrm{bc}$ & $41.44 \mathrm{ab}$ & $8.00 \mathrm{a}$ & $14.04 \mathrm{a}$ & $13.54 \mathrm{a}$ & $14.84 \mathrm{ab}$ \\
\hline & F3-13 & $62.75 \mathrm{ab}$ & $36.16 \mathrm{abc}$ & $4.26 \mathrm{abc}$ & $10.99 \mathrm{c}$ & $12.85 \mathrm{ab}$ & $12.12 \mathrm{~b}$ \\
\hline & F6-23 & $67.83 \mathrm{a}$ & $26.88 \mathrm{c}$ & $5.00 \mathrm{abc}$ & $13.57 \mathrm{ab}$ & $13.18 \mathrm{ab}$ & $14.23 \mathrm{ab}$ \\
\hline & F16-12 & $62.97 \mathrm{~b}$ & $32.91 \mathrm{bc}$ & $5.66 \mathrm{abc}$ & $11.39 \mathrm{bc}$ & $12.13 \mathrm{ab}$ & $13.36 \mathrm{~b}$ \\
\hline & F6-14 & $57.95 \mathrm{abc}$ & $36.16 \mathrm{abc}$ & $6.66 \mathrm{abc}$ & $11.79 \mathrm{abc}$ & $11.76 \mathrm{ab}$ & $13.57 \mathrm{~b}$ \\
\hline & AN-184 & $68.25 \mathrm{~b}$ & $27.33 \mathrm{c}$ & $4.25 \mathrm{abc}$ & $11.51 \mathrm{bc}$ & $14.84 \mathrm{a}$ & $13.84 \mathrm{ab}$ \\
\hline \multicolumn{2}{|r|}{ MSD } & 12.22 & 12.54 & 4.22 & 2.29 & 4.84 & 3.00 \\
\hline
\end{tabular}

LOC=location; SYS=systems; VAR=varieties; $M S D=$ Minimum significant difference; NS=Normal seedlings; $A S=A n o r m a l$ seedlings; $S W G=$ Seeds without germinating; DW=Dry seedling weight; $\mathrm{PL}=$ Plumule length; $\mathrm{RL}=$ Radicle length. Within columns, means followed by the same letter are not significantly different according to Tukey (P $\leq 0.05)$.

In the means comparison test for normal seedlings (NS) in the localities, there was a difference between letters positioning L2 with $64.0 \%$ of germination and L1 with $61.0 \%$ of germination; this is linked to the fertility of the spikes, which was reflected in the number of seeds per ear which was higher than in L2, due to hydric stress and because of the agronomic management in this locality, which in the end had a positive effect on the seed's germination. In the case of systems, for the means comparison for the system without cut there was $72.0 \%$ of germination, compared to the system with cut with $52.22 \%$ of germination; the variation is directly related since due to the cut the plant had lower fertility that was reflected in a lower number of seeds per ear that and number of spikelets per spike. For the case of varieties the one with higher percentage of germination was variety 2 with $69.44 \%$ and variety 7 with 67.83\%. However, Mendoza et al. (2011) report values that fluctuate between 81.0 and $94.25 \%$ of germination. In the means comparison test for abnormal seedlings (AS) for localities, abnormal seedlings in L1 was higher, 35.0\%, and in L2 it was 31.10\%. In the case of the systems the highest percentage of abnormal seedlings was for the system with cut of $44.0 \%$ and in the system without cut of $23.0 \%$. For varieties the one that presented $45.75 \%$ of seedlings was variety 1 . For the means comparison test for seeds without germinating (SWG) in the case of the localities, it was L2 with 6.0\% and L1 
with $4.0 \%$. For both production systems there was similar percentage of $5.0 \%$ of seeds without germinating.

In the means comparison test for the variable dry weight (DW) for the localities, L2 had higher weight with $13.18 \mathrm{mg} /$ seedling in relation to locality 1 with $11.29 \mathrm{mg} /$ seedling. In the case of production systems for the system without cut $12.54 \mathrm{mg} /$ seedling, and the system with cut $11.76 \mathrm{mg} /$ seedling. Within the varieties the one that obtained the highest value in this variable was variety 5 (Bicentenario) with $14.04 \mathrm{mg} /$ seedling. However, (Fernández et al., 2015) report that in wheats the varieties with high vigor in favorable environments have a positive repercussion in the dry weight per seedling, since vigorous seedlings and with high emergence speed increase the dry weight.

For the variable plumule length (PL) for the case of localities, in the means comparison with the same letter it behaved in L2 with a value of $13.01 \mathrm{~cm}$ and in L1 with a value of $12.0 \mathrm{~cm}$. For the case of the production systems there was no difference in the means test since the letter was similar for the two systems; for the system with cut the value was $12.53 \mathrm{~cm}$ and for the system without cut it was $12.38 \mathrm{~cm}$. In this same variable for the means comparison test for varieties, two resulted with the same letter, variety 10 (AN-184) with a value of $14.84 \mathrm{~cm}$ and variety 5 (Bicentenario) with a value of $13.54 \mathrm{~cm}$. Fernández et al., 2015 mention for wheat that plumule length is favored by the variety, production environment, and agronomic management. Likewise, varieties with high germination vigor impact positively in the emergence speed, and in addition in environments with favorable conditions there is an acceptable growth and development of seedlings in their diverse phenological stages, which has an impact in higher yield.

For the results of the variable radicle length (RL) in the localities, Francisco I. Madero presented a higher value with $15.36 \mathrm{~cm}$ in relation to Matamoros with a value of $12.73 \mathrm{~cm}$. For the case of the production systems, the system without cut with a length of $14.34 \mathrm{~cm}$ and the system with cut with a length of $13.49 \mathrm{~cm}$. For the varieties, genotype F13-17 presented the highest value, of $16.63 \mathrm{~cm}$, which is directly related to the vigor of the seed and its capacity to be established in the field.

\section{CONCLUSIONS}

In this study the locality of Matamoros showed higher grain yield in the genotypes evaluated, because they were given better conditions of agronomic management for the production, compared to the location of Francisco I. Madero. In the seed production systems, the one that showed better yield was the system without cut, since when doing a fodder cut the phenology of the crop was delayed, as well as an effect on the regrowth of stems and the number of spikelets, which influences its fertility and is directly related to the number of grains per spike. For the seed production systems, the system without cut stood out in the variables plant height, spike length, number of spikelets per spike, and number of seeds per ear. In the analysis results of physiological quality, a higher percentage of germination and higher dry weight of the seedling and radicle length 
was found, in the seed harvested in the locality of Francisco I. Madero. In the locality of Matamoros, a higher percentage of abnormal seedlings was found, with this being an indicator of the deterioration of the seed, related to a lower physiological quality. In terms of the seeds production systems, the system without cut presented high values in percentage of germination, dry weight of the seedling and radicle length. Therefore, it is concluded that for the production of triticale seeds, the production systems do affect the yield and the physiological quality of the seeds, so this study finds that the seed production system without cut was the ideal.

\section{REFERENCES}

Ammar, K. (2013). Promoción y mejoramiento del triticale. Revista Enlace, 16,p. 27-29.

Beji, S. (2016). Yield and quality of dual-purpose barley and triticale in a semi-arid environment in Tunisia. African Journal of Agricultural Research. Vol. 11(30): 2730-2735 p.

Bassu, S., Asseng S., Giunta F., Motzo, R. (2013). Optimizing triticale sowing densities across the Mediterranean Basin. Field Crops Research. 144: 167-178 p.

Centro Internacional de Mejoramiento de Maíz y Trigo (CIMMYT). (1976). Trigo x Centeno=Triticale. CIMMYT. 5: 16 p.

Estrada, C. G., Slafer G., Miralles D. (2012). Differences in yield, biomass and their components between triticale and wheat grown under contrasting water and nitrogen environments. Field Crops Research. 128: 167-179 p.

Fernández, S.R., Carballo, C.A., Villaseñor, M.H.E., Hernández, L.A. (2015). Calidad de la semilla de trigo de temporal en función al ambiente de producción. Revista Mexicana de Ciencias Agrícolas. Vol 6: 1239-1251 p.

Giunta, F., Cabigliera, A., Virdis, A., Motzo, R. (2015). Dual-purpose use affects phenology of triticale. Field Crops Research. 183: $111-116 \mathrm{p}$.

Instituto Nacional de Estadística, Geografía e Informática. (INEGI). (2009). Prontuario de información geográfica municipal de los Estados Unidos Mexicanos. Matamoros y Francisco I. Madero, Coahuila de Zaragoza, México.

Mendoza, E. M., Cortez-Baheza, E., Rivera-Reyes, J. G., Rangel-Lucio, J. A., Andrio-Enríquez, E., \& Cervantes-Ortiz, F. (2011). Época y densidad de siembra en la producción y calidad de semilla de triticale (X Triticosecale Wittmack). Agronomía Mesoamericana. 22(2), 309-316.

Mendoza, E. M., Lucio, J. R., Reyes, J. R., Acevedo, L. G., \& Martínez, E. M. (2014). Evaluación de la fertilización integral en la producción de semilla de triticale (X Triticum secale Wittmack). Revista Internacional de Botánica Experimental. 83:93-100 p.

Paccapelo, H., Ferreira, V., Picca, A., Ferrari, E., Domínguez, R., Grassi, E., Ferreira, A., Di Santo, H., Castillo, E. (2017). Triticale (X Triticosecale Wittmack) Rendimiento y sus componentes en un ambiente semiáridos de la Argentina. Chilean Journal of Agricultural and Animal Sciences. 33: 45-58 p.

Servicio de Información Agroalimentaria y Pesquera (SIAP). (2019). Avance de Siembras y Cosechas. Resumen nacional por estado. Consultado el 28 de agosto de 2020 en http://infosiap.siap.gob.mx/agricola_siap_gobmx/ AvanceNacionalCultivo.doc

Servicio Meteorológico Nacional (SMN). (2019). Información Estadística Climatológica. Normales Meteorológicas 1981-2010. Municipios de Matamoros y Francisco I. Madero, Coahuila de Zaragoza. http://smn.conagua.gob.mx/ (Mayo 2020).

Servicio Nacional de Inspección y Certificación de Semillas (SNICS). (2020). Producción de semilla calificada por el SNICS. Boletín informativo de producción de semilla certificada del SNICS, 1, 16.

Velasco, L. J.L., Soto O.R., Ail C.C.E., Grimaldo J.O., Avilés M.S.M., Lozano, D.A.J. (2020). Rendimiento de biomasa y grano en variedades de triticale en el valle de Mexicali. Revista Mexicana de Ciencias Agrícolas, 11(5): 1097-1109 p.

Velázquez, M. J.L. (2018). Estimación de biomasa en triticales con índices de vegetación. Tesis de Licenciatura. Ingeniero Agrónomo en Producción. Universidad Autónoma Agraria Antonio Narro. Buenavista, Saltillo, Coahuila. 12 p. 